\title{
Emergence of Tan Spot Disease Caused by Toxigenic Pyrenophora tritici-repentis in Australia Is Not Associated with Increased Deployment of Toxin-Sensitive Cultivars
}

\author{
R. P. Oliver, M. Lord, K. Rybak, J. D. Faris, and P. S. Solomon
}

First, second, third, and fifth authors: Australian Centre of Necrotrophic Plant Pathogens, Health Sciences, SABC, Murdoch University, WA 6150, Australia; and fourth author: U.S. Department of Agriculture-Agricultural Research Service (USDA-ARS), Cereal Crops Research

Unit, Red River Valley Agricultural Research Center, Northern Crop Science Lab, Fargo, ND 58105. Accepted for publication 23 November 2007.

\begin{abstract}
Oliver, R. P., Lord, M., Rybak, K., Faris, J. D., and Solomon, P. S. 2008. Emergence of tan spot disease caused by toxigenic Pyrenophora triticirepentis in Australia is not associated with increased deployment of toxinsensitive cultivars. Phytopathology 98:488-491.

The wheat disease tan (or yellow leaf) spot, caused by Pyrenophora tritici-repentis, was first described in the period 1934 to 1941 in Canada, India, and the United States. It was first noted in Australia in 1953 and only became a serious disease in the 1970s. The emergence of this disease has recently been linked to the acquisition by $P$. tritici-repentis of the ToxA gene from the wheat leaf and glume blotch pathogen, Stagonospora nodorum. ToxA encodes a host-specific toxin that interacts with the product of the wheat gene $T s n 1$. Interaction of ToxA with the dominant allele of Tsn1 causes host necrosis. P. tritici-repentis races lacking ToxA

Although the emergence and spread of tan spot had been attributed to the adoption of minimum tillage practices, we wished to test the alternative idea that the planting of Tsnl wheat lines may have contributed to the establishment of the pathogen in Australia. To do this, wheat cultivars released in Australia from 1911 to 1986 were tested for their sensitivity to ToxA. Prior to $1941,16 \%$ of wheat cultivars were ToxA-insensitive and hence, all other factors being equal, would be more resistant to the disease. Surprisingly, only one of the cultivars released since 1940 was ToxA insensitive, and the area planted to ToxA-insensitive cultivars varied from 0 to a maximum of only $14 \%$ in New South Wales. Thus, the majority of the cultivars were ToxA-sensitive both before and during the period of emergence and spread of the disease. We therefore conclude that the spread of $P$. tritici-repentis in Australia cannot be causally linked to the deployment of ToxA-sensitive cultivars.
\end{abstract} give minor indistinct lesions on wheat lines, whereas wheat lines expressing the recessive $t s n 1$ are significantly less susceptible to the disease.
Additional keywords: horizontal gene transfer, phylogeography.
The spread of plant diseases from one region to another is of immense historical, theoretical, and practical importance in plant pathology $(4,20,24,27,36,38)$. Establishment of a disease in a new location requires that the spores (or other propagules) must both be disseminated and also thrive in the new location. The recent emergence of the wheat disease tan (or yellow) spot caused by Pyrenophora (syn. Helminthsporium or Drechslera) triticirepentis ([Died.] Drechsler) provides a unique opportunity to test hypotheses on the causal factors required for intercontinental disease spread.

Wheat diseases have been carefully studied and catalogued in all wheat growing areas of the world since antiquity. We can therefore be reasonably certain that tan spot, currently a regular and damaging disease of wheat causing major losses in many parts of the world $(6,7,23,28,40)$, did not emerge significantly prior to its description as the causal organism in the period 1934 to $1941(1,2,5,19,29)$. The causal pathogen, $P$. tritici-repentis (Ptr) was described by Drechsler in 1923 (12) but was noted only as an occasional pathogen of grasses (18).

Pathogenicity of $P$. tritici-repentis is largely dependent on the production of three toxins of which ToxA is the best characterized and most important. ToxA is a small, secreted protein and acts as a host-specific toxin causing necrosis in susceptible cultivars $(9,37,41)$. Sensitivity to the toxin is mediated by the Tsnl gene

Corresponding author: R. P. Oliver; E-mail address: roliver@murdoch.edu.au

doi:10.1094/PHYTO-98-5-0488

(C) 2008 The American Phytopathological Society
(13) located on wheat chromosome arm 5BL (26). Genotypes with the dominant allele of $T s n 1$ are significantly more susceptible to the disease (16).

The disease caused by $P$. tritici-repentis is called either yellow (leaf) spot (in Australia, South Africa, and Russia) or tan spot (in the Americas, Bulgaria, and UK) (10). ToxA produces a necrotic reaction in keeping with the name tan spot, whereas the other toxins produce chlorotic reactions, perhaps suggesting the name yellow spot $(8,11,21)$. Isolates carrying each of the toxins are globally distributed (15). We can conclude that the different names given to the disease reflect historical accident rather than consistent phenotypic differences in symptom expression. Therefore, to avoid confusion, the disease will be referred to as tan spot in this paper.

We have recently obtained evidence that the ToxA gene was inter-specifically transferred to $P$. tritici-repentis from the related wheat pathogen Stagonospora nodorum (Sn) (17). The sequences of ToxA genes from $S$. nodorum were shown to be highly variable, consistent with a long history and positive selection for variation (39). In contrast, ToxA genes from Ptr isolates from around the world were identical, which is consistent with a more recent acquisition of the gene. In contrast, SnToxA sequences from $S$. nodorum were shown to be highly variable, consistent with a long history and positive selection for variation (39). Three factors, (i) the very recent emergence of tan spot, (ii) the evidence of interspecific gene transfer, and (iii) the enhanced virulence of strains carrying ToxA, led us to hypothesize that the acquisition of the gene was a critical factor in establishing the tan spot disease and promoting its dissemination. It is not clear how Ptr has spread 
throughout the world, but seed has been implicated as a possible means of long distance dissemination $(18,43)$.

The hypothesis. Tan spot was first noticed in Australia in the early 1950s (44). By the 1970s it had spread and become a severe problem in parts of Queensland, New South Wales, and Western Australia $(30,32,33)$. The very recent emergence of the disease in Australia, the excellent records of cultivars released and sown and the availability of those cultivars for testing ToxA sensitivity provided a unique opportunity to examine a possible factor behind the establishment of the disease. We have therefore tested the $T s n 1$ phenotype and genotype of wheat cultivars released and sown prior to and during the spread of tan spot to determine whether the inadvertent use of the more susceptible $T s n 1$ cultivars might have contributed to the spread of the disease in Australia.

Methodology and results. Wheat accessions representing many of the cultivars released between 1911 and 1970 and a sample of more modern cultivars were obtained from the Australian Winter Cereal Culture Collection and the Department of Agriculture and Food, Western Australia (Table 1). Fifty-three cultivars were tested by infiltrating purified ToxA preparations into leaves of 3-week-old plants and examining the reactions 5 days later (25). The leaf reactions fell clearly into only two categories, necrosis or no reaction; no intermediate reactions were detected (data not shown). Only 8 of the 53 accessions were insensitive to the toxin and hence were genotypically $t s n 1$. Interestingly the majority of the tsnl varieties were released before 1941. Only 1 of the 26 varieties released after 1941 was tsn 1; Olympic (Table 1). The 53 wheat samples were analyzed using microsatellite markers linked to Tsnl (26). The markers have been estimated to flank the $T s n 1$ locus at genetic distances of 0.2 and $0.6 \mathrm{cM}$. All ToxA-sensitive wheat lines and six of the eight ToxA-insensitive lines displayed the fragment sizes expected for

TABLE 1. The phenotype was assayed using the reaction to ToxA; the genotype was assayed using Tsn1-linked microsatelite markers

\begin{tabular}{|c|c|c|c|c|c|}
\hline Name $^{\mathrm{a}}$ & Year released & Areas grown & Phenotype $t s n=0, T s n=1$ & Genotype $t s n=0, T s n=1$ & Years of major use \\
\hline Merredin & 1911 & WA & 0 & 0 & \\
\hline Nabawa & 1915 & NSW, WA, SA, Commonwealth & 1 & 1 & $1929-48$ \\
\hline Ford & 1916 & & 1 & 1 & $1925-60$ \\
\hline Novo & 1920 & Qld & 0 & 1 & \\
\hline Waratah & 1921 & NSW & 1 & 1 & $1925-52$ \\
\hline Gluclub & 1922 & WA & 1 & 1 & \\
\hline Flora & 1923 & Qld & 1 & 1 & \\
\hline Ghurka & 1924 & Vic, Commonwealth, & 0 & 0 & $1938-48$ \\
\hline Ranee & 1924 & NSW, SA, Vic & 1 & 1 & $1929-51$ \\
\hline Free Gallipoli & 1925 & Vic, Commonwealth & 1 & 1 & $1925-37$ \\
\hline Dundee & 1927 & NSW, SA, Vic & 1 & 1 & $1932-52$ \\
\hline Gular & 1927 & NSW & 0 & 0 & \\
\hline Bencubbin & 1929 & WA, Commonwealth, SA, NSW & 1 & 1 & $1935-74$ \\
\hline Sea Foam & 1930 & Qld & 1 & 1 & \\
\hline Lawrence & 1932 & Qld & 1 & 1 & \\
\hline Puora & 1932 & Qld & 1 & 1 & \\
\hline Festival & 1936 & Qld & 1 & 1 & $1952-65$ \\
\hline Puglu & 1938 & Qld & 1 & 1 & \\
\hline Bungulla & 1939 & WA & 1 & 1 & $1945-51$ \\
\hline Magnet & 1939 & Vic & 0 & 0 & $1948-57$ \\
\hline Puseas & 1939 & Qld & 0 & 1 & \\
\hline Wongoondy & 1940 & WA & 1 & 1 & \\
\hline Pindar & 1941 & Vic & 1 & 1 & \\
\hline Quadrat & 1941 & Vic, Commonwealth & 0 & 0 & $1948-57$ \\
\hline Warigo & 1941 & $\mathrm{SA}$ & 1 & 1 & $1948-64$ \\
\hline Kondut & 1943 & WA & 1 & 1 & \\
\hline Charter & 1945 & Qld, & 1 & 1 & $1945-59$ \\
\hline Gabo & 1945 & NSW, WA, SA & 1 & 1 & $1946-70$ \\
\hline Insignia & 1946 & Vic, SA, Commonwealth, WA & 1 & 1 & $1950-75$ \\
\hline Kendee & 1946 & NSW & 1 & 1 & $1948-60$ \\
\hline Pinnacle & 1946 & Vic & 1 & 1 & $1950-74$ \\
\hline Glenwari & 1948 & NSW & 1 & 1 & $1951-71$ \\
\hline Dirk & 1949 & SA, & 1 & 1 & \\
\hline Sabre & 1952 & NSW, SA, & 1 & 1 & $1957-65$ \\
\hline Spica & 1952 & Qld & 1 & 1 & $1955-76$ \\
\hline Olympic & 1956 & Vic, NSW & 0 & 0 & $1958-88$ \\
\hline Heron & 1959 & NSW, W A, S A, Vic & 1 & 1 & $1962-80$ \\
\hline Falcon & 1960 & NSW & 1 & 1 & $1962-81$ \\
\hline Gala & 1960 & Qld & 1 & 1 & \\
\hline Mengavi & 1960 & NSW & 1 & 1 & $1962-71$ \\
\hline Eagle & 1969 & Qld & 1 & 1 & \\
\hline Gatcher & 1969 & Qld, NSW & 1 & 1 & \\
\hline Condor & 1973 & NSW & 1 & 1 & \\
\hline Egret & 1973 & NSW & 1 & 1 & \\
\hline Kite & 1973 & Qld, NSW & 1 & 1 & \\
\hline Songlen & 1975 & Qld, NSW & 1 & 1 & \\
\hline Cook & 1977 & Qld, NSW & 1 & 1 & \\
\hline Tincurrin & 1977 & WA & 1 & 1 & \\
\hline Miling & 1978 & WA & 1 & 1 & \\
\hline Banks & 1979 & Qld, NSW & 1 & 1 & \\
\hline Eradu & 1981 & WA & 1 & 1 & \\
\hline Gutha & 1982 & WA & 1 & 1 & \\
\hline Kulin & 1986 & WA & 1 & 1 & \\
\hline
\end{tabular}

a Wheat varieties tested in this study.

b Data available for NSW only. 
the Tsnl and tsnl genotypes, respectively. Interestingly, two ToxA-insensitive lines (Novo and Puseas) gave the fragment sizes expected for the Tsn1 genotype (26) indicating recombination has occurred in these lines (Table 1).

A sample of seven isolates of $P$. tritici-repentis was obtained from P. Williamson, Queensland Department of Primary Industry, to determine whether they carried the ToxA gene. These isolates were collected between 1978 and 2001 from sites in Queensland, Victoria, New South Wales, and Western Australia. The ToxA primers directed the amplification of the expected 134-bp fragment in all 7 cases (17) (data not shown).

The area planted to each wheat variety is recorded for New South Wales (14). Figure 1 shows the area planted to tsn 1 varieties as a percentage of the total wheat acreage. ToxA-insensitive varieties constituted never more than $14 \%$ of the area planted, and Olympic was the sole recorded tsn 1 variety cultivated after 1957. The maximum area of tsnl utilization was in the period 1960 to 1975 during which tan spot emerged as a wheat disease of major importance.

Significance and conclusions. Amongst the crop diseases to have emerged in recent decades, wheat tan spot is both economically very significant and particularly well documented. Tan spot was first noted in Australia in the 1950s (44). By the 1970s it was a major disease in Australia causing yield losses up to $48 \%$ $(31,32,34)$.

ToxA is an important pathogenicity factor for Ptr and the ToxA gene is commonly found in Ptr isolates from diverse geographical regions. Although no large studies of Australian populations of tan spot have been published, all isolates produce necrotic lesions on ToxA-sensitive cultivars and all of the seven isolates surveyed carried ToxA (35). Thus, the purpose of this study was to test the hypothesis that $P$. tritici-repentis might have become established in Australia as a result of ToxA-insensitive cultivars being dropped in favor of sensitive cultivars during the decades before establishment of the disease. To test this, we collected wheat cultivars released in Australia between 1911 and 1986 and tested their reaction to ToxA. The pattern we observed did not support our hypothesis. Instead, we found that the large majority of cultivars released in that period were $T o x A$-sensitive, with the areas planted to $T o x A$-insensitive cultivars varying between 0 and $14 \%$. Indeed, the peak period of utilization of ToxA-insensitive varieties was in the period 1960 to 1974 , by the end of which the pathogen was firmly established. New South Wales contains regions comparable with both the summer (Queensland) and winter rain-fed (Victorian, South Australian, and Western Australian) regions and so can be regarded as indicative of the situation in the rest of Australia. We can conclude therefore that the removal of ToxAinsensitive cultivars was not a major factor in the emergence of the disease.

The recessive allele $t s n 1$ confers toxin insensitivity but only partial disease resistance and only to ToxA-producing races of the

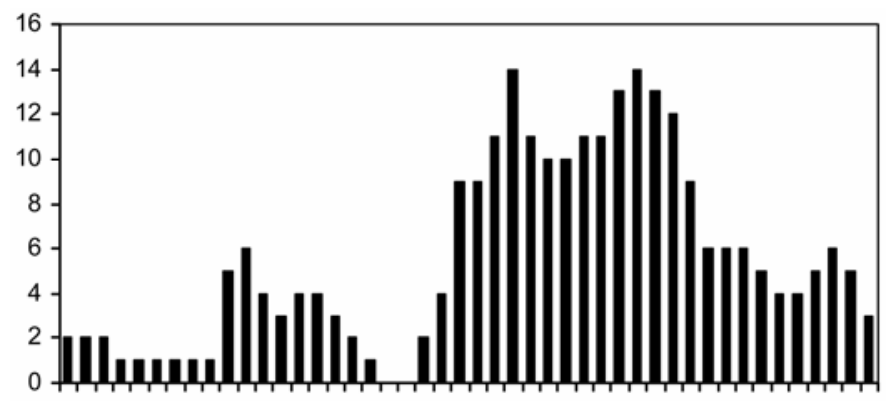

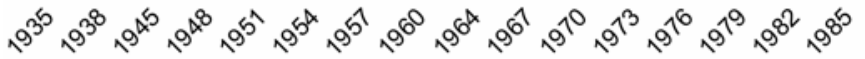

Fig. 1. A bar graph presenting the percent total area planted in ToxAinsensitive wheat varieties from 1935 to 1985 in New South Wales, including the 1970s when the disease emerged as an economic problem (12). fungus. Olympic, the only tsn 1 variety grown between 1958 and the 1980s, was described as susceptible to tan spot with yield losses of $39 \%$, though it performed significantly better than other cultivars described as very susceptible, such as Banks, with losses of $48 \%$ (33). The symptoms on Olympic were spreading chlorotic, rather than necrotic, lesions consistent with insensitivity to ToxA but sensitivity to ToxB or ToxC (G. Platz, personal communication). Based on overall tan spot score, Rees concluded that the cultivars introduced in the 1960s and 1970s were more susceptible to the disease than the cultivars they replaced (35). More work on the $P$. tritici-repentis populations and tan spot resistance genes in Australia is needed to fully determine whether genetic or, more likely, agronomic factors such as the introduction of minimum tillage, can explain the success of tan spot $(3,11)$.

The possible role of $T s n 1$ in the spread of tan spot in western Canada has also been investigated (22). Tan spot remained sporadic until the 1970 s but since then has been a regular and damaging disease. $T s n 1$ wheats were widely planted from as early as the late 1800 s, nearly disappeared by the 1950 s but were inadvertently reintroduced in the 1960s. This pattern provides no clear correlation between the incidence of the disease and the relative frequencies of $T s n 1$ - and $t s n 1$-containing cultivars. Here, as in Australia, other factors appear to have dominated.

The emergence of tan spot invites comparison with southern corn leaf blight (42). This disease, caused by race $\mathrm{T}$ isolates of Cochliobolus heterostrophus, is also attributed to a host-specific toxin. Maize carrying a specific mutation of the mitochondrial DNA associated with Texas cytoplasmic male sterility (T-cms) was found to be specifically sensitive to the toxin and susceptible to the disease. Race $\mathrm{T}$ isolates were first observed in the Philippines in 1961 and in the United States in 1968. The epidemic of 1970 which caused 20 to $30 \%$ losses was unprecedented in modern times. Shortly thereafter T-cms corn was abandoned and the disease has retreated (45). T-cms had been introduced into maize cultivars only a decade or so before the emergence of the new epidemic, whereas our results show that $T s n 1$ wheat has been present at least 50 years before tan spot became a major disease. The spectacular rise and fall of race $\mathrm{T} C$. heterostrophus is explained by the devastating effect of T-toxin on T-cms maize (allied to its hypersusceptibility to other diseases) and the fact that $85 \%$ of the United States maize crop carried the susceptibility gene in 1970 to 1971 (42). Such varieties were quickly replaced. In contrast, the effect of ToxA on the virulence of $P$. triticirepentis is more measured and is ameliorated by the presence of at least two other significant toxins. Expression of the sensitivity genes does not lead to catastrophic disease. These factors may explain why the sensitivity allele $T s n 1$ seems to have been present at high frequency decades prior to the emergence of the pathogen as a serious disease.

\section{ACKNOWLEDGMENTS}

The work was funded by the Australian Grains Research and Development Corporation GRDC. We thank S. Meinhardt (NDSU) for supplying the purified ToxA, G. Grimes and R. Loughman for the wheat cultivars, P. Williamson for the tan spot isolates, and T. Friesen (USDA) and B. McDonald (ETH, Switzerland) for discussions and comments on the manuscript.

\section{LITERATURE CITED}

1. Anonymous. 1937. Diseases of Cereal Crops. Canadian Plant Disease Survey 17:5. http://www.cps-scp.ca/download/cpds-archive/vol17.

2. Anonymous. 1939. Pages 12-14 in: Diseases of Cereal Crops. Canadian Plant Disease Survey. http://www.cps-scp.ca/download/cpds-archive/ vol19/CPDS_Vol_19_No_1_(1-23)1939.pdf.

3. Bailey, K. L., and Duczek, L. J. 1996. Managing cereal diseases under reduced tillage. Can. J. Plant Pathol. 18:159-167.

4. Banke, S., and McDonald, B. A. 2004. Migration patterns among global populations of the pathogenic fungus Mycosphaerella graminicola. Mol. 
Ecol. 14:1881-1896.

5. Barrus, M. F. 1942. A disease of wheat newly recorded for this countryYellow spot disease of wheat in New York State. Plant Dis. Rep. 26:246.

6. Bhathal, J., Loughman, R., and Speijers, J. 2003. Yield reduction in wheat in relation to leaf disease from yellow (tan) spot and septoria nodorum blotch. Eur. J. Plant Pathol. 109:435-443.

7. Carmona, M. A., Ferrazini, M., and Barreto, D. E. 2006. Tan spot of wheat caused by Drechslera tritici-repentis: Detection, transmission, and control in wheat seed. Cereal Res. Commun. 34:1043-1049.

8. Ciuffetti, L. M., Francl, L. J., Ballance, G. M., Bockus, W. W., Lamari, L., Meinhardt, S. W., and Rasmussen, J. B. 1998. Standardization of toxin nomenclature in the Pyrenophora tritici-repentis/wheat interaction. Can. J. Plant Pathol. 20:421-424.

9. Ciuffetti, L. M., Tuori, R. P., and Gaventa, J. M. 1997. A single gene encodes a selective toxin causal to the development of tan spot of wheat. Plant Cell 9:135-144.

10. Cook, R. J., and Yarham, D. J. 1989. Occurrence of tan spot of wheat caused by Pyrenophora tritici-repentis on wheat in England and Wales in 1987. Plant Pathol. 38:101-102.

11. De Wolf, E. D., Effertz, R. J., Ali, S., and Francl, L. J. 1998. Vistas of tan spot research. Can. J. Plant Pathol. 20:349-370.

12. Drechsler, C. 1923. Some graminicolous species of Helminthosporium. I. J. Agric. Res. 24:641-739.

13. Faris, J. D., Anderson, J. A., Francl, L. J., and Jordahl, J. G. 1996. Chromosomal location of a gene conditioning insensitivity in wheat to a necrosis-inducing culture filtrate from Pyrenophora tritici-repentis. Phytopathology 86:459-463.

14. Fitzsimmons, R. 1987. NSW wheat variety statistics 1945-1985. NSW DPI, Sydney, NSW, Australia.

15. Friesen, T. L., Ali, S., Klein, K. K., and Rasmussen, J. B. 2005. Population genetic analysis of a global collection of Pyrenophora triticirepentis, causal agent of tan spot of wheat. Phytopathology 95:1144-1150.

16. Friesen, T. L., Rasmussen, J. B., Kwon, C. Y., Ali, S., Francl, L. J., and Meinhardt, S. W. 2002. Reaction of Ptr ToxA-insensitive wheat mutants to Pyrenophora tritici-repentis race 1. Phytopathology 92:38-42.

17. Friesen, T. L., Stukenbrock, E. H., Liu, Z. H., Meinhardt, S., Ling, H., Faris, J. D., Rasmussen, J. B., Solomon, P. S., McDonald, B. A., and Oliver, R. P. 2006. Emergence of a new disease as a result of interspecific virulence gene transfer. Nat. Genet. 38:953-956.

18. Hosford, R. M. 1982. Tan spot-developing knowledge 1902-1981, virulent races and wheat differentials, methodology, rating systems, other leaf diseases, literature. Pages 1-24 in: Tan Spot of Wheat and Related Diseases Workshop. R. M. Hosford, ed. North Dakota Agricultural Experiment Station, Fargo, North Dakota.

19. Johnson, A. J. 1942. Helminthosporium tritici-vulgaris on wheat in Maryland. Plant Dis. Rep. 26:246-247.

20. Kluza, D. A., Vieglais, D. A., Andreasen, J. K., and Peterson, A. T. 2007. Sudden oak death: Geographic risk estimates and predictions of origins. Plant Pathol. 56:580-587.

21. Lamari, L., and Bernier, C. C. 1991. Genetics of tan necrosis and extensive chlorosis in tan spot of wheat caused by Pyrenophora triticirepentis. Phytopathology 81:1092-1095.

22. Lamari, L., McCallum, B. D., and dePauw, R. M. 2005. Forensic pathology of Canadian bread wheat: The case of tan spot. Phytopathology 95:144-152.

23. Lamari, L., Strelkov, S. E., Yahyaoui, A., Amedov, M., Saidov, M., Djunusova, M., and Koichibayev, M. 2005. Virulence of Pyrenophora tritici-repentis in the countries of the Silk Road. Can. J. Plant Pathol. 27:383-388.

24. Linde, C. C., Zhan, J., and McDonald, B. A. 2002. Population structure of
Mycosphaerella graminicola: From lesions to continents. Phytopathology 92:946-955

25. Liu, Z. H., Faris, J. D., Meinhardt, S. W., Ali, S., Rasmussen, J. B., and Friesen, T. L. 2004. Genetic and physical mapping of a gene conditioning sensitivity in wheat to a partially purified host-selective toxin produced by Stagonospora nodorum. Phytopathology 94:1056-1060.

26. Lu, H. J., Fellers, J. P., Friesen, T. L., Meinhardt, S. W., and Faris, J. D. 2006. Genomic analysis and marker development for the Tsn1 locus in wheat using bin-mapped ESTs and flanking BAC contigs. Theor. Appl. Genet. 112:1132-1142

27. McDonald, B. A., and Linde, C. 2002. Pathogen population genetics, evolutionary potential, and durable resistance. Annu. Rev. Phytopathol. 40:349-379.

28. Mikhailov, L. A., and Prigorovskaya, T. I. 2000. Yellow leaf spot of wheat-Pyrenophora tritici-repentis. Mikol. Fitopatol. 34:7-16.

29. Mitra, M. 1934. A leaf spot disease of wheat caused by Helminthsporium tritici-repentis Died. Indian J. Agric. Sci. 4:692-700.

30. Murray, G., and Brown, J. 1987. The Incidence and Relative Importance of Wheat Diseases in Australia. Aust. J. Plant Pathol. 16:34-37.

31. Rees, R. G., Mayer, R. J., and Platz, G. J. 1981. Yield losses in wheat from yellow spot: A disease-loss relationship derived from single tillers. Aust. J. Agric. Res. 32:851-859.

32. Rees, R. G., and Platz, G. J. 1979. The occurrence and control of yellow spot of wheat in north-eastern Australia. Aust. J. Exp. Agric. 19:369-372.

33. Rees, R. G., and Platz, G. J. 1983. Effects of Yellow spot on wheat; Comparison of epidemics at different stages of crop development. Aust. J. Agric. Res. 34:39-46.

34. Rees, R. G., Platz, G. J., and Mayer, R. J. 1982. Yield losses in wheat from yellow spot: Comparison of estimates derived from single tillers and plots. Aust. J. Agric. Res. 33:899-908.

35. Rees, R. G., Platz, G. J., and Mayer, R. J. 1988. Susceptibility of Australian wheats to Pyrenophora tritici-repentis. Aust. J. Agric. Res. 39:141-151.

36. Ristaino, J. B., Groves, C. T., and Parra, G. R. 2001. PCR amplification of the Irish potato famine pathogen from historic specimens. Nature 411: 695-697.

37. Strelkov, S. E., and Lamari, L. 2003. Host-parasite interactions in tan spot Pyrenophora tritici-repentis of wheat. Can. J. Plant Pathol. 25:339349.

38. Stukenbrock, E. H., Banke, S., and McDonald, B. A. 2006. Global migration patterns in the fungal wheat pathogen Phaeosphaeria nodorum. Mol. Ecol. 15:2895-2904

39. Stukenbrock, E. H., and McDonald, B. A. 2007. Geographic variation and positive diversifying selection in the host specific toxin SnToxA. Mol. Plant Pathol. I8:321-332.

40. Todorova, M. 2006. First report of tan spot caused by Pyrenophora triticirepentis (anamorph Drechslera tritici-repentis) in Bulgaria. Plant Pathol. 55:305-305.

41. Tomas, A., Feng, G. H., Reeck, G. R., Bockus, W. W., and Leach, J. E. 1990. Purification of a cultivar-specific toxin from Pyrenophora triticirepentis, causal agent of tan spot of wheat. Mol. Plant-Microbe Interact. 3:221-224.

42. Ullstrup, A. J. 1972. The impacts of the southern corn leaf blight epidemics of 1970-71. Annu. Rev. Phytopathol. 10:37-50.

43. Valder, P. G. 1954. Yellow leaf spot and pink grain in wheat. Agric. Gaz. NSW. 65:36-37.

44. Valder, P. G., and Shaw, D. E. 1953. Yellow spot disease of wheat in Australia. P. Linn. Soc. NSW. 77:323-330.

45. Yoder, O. 1980. Toxins in plant pathogenesis. Annu. Rev. Phytopathol. 18:103-129. 